\title{
COVID-19 RISK MANAGEMENT PERSPECTIVES OF THE EUROPEAN CAPITAL OF CULTURE: WHAT NOW?
}

\author{
Aleksandra S. Dragin \\ Zrinka Zadel \\ Maja B. Mijatov \\ Vladimir Stojanović \\ Tamara Jovanović \\ Lazar Lazić \\ Tamara Zelenović Vasiljević \\ Nemanja Milenković
}

https://doi.org//10.20867/tosee.06.14

\begin{abstract}
Purpose - Tourism industry is facing unexpected economic consequences of the COVID-19 outbreak, indicating the need for knowledge that would support the crisis management in rapidly changed market conditions. Such difficulties increased the managers' and decision makers' anxiety and put a pressure on actions with uncertain outcomes. Tourism has become a top priority in Serbia, which is supported by the fact that Novi Sad was declared European Capital of Culture (ECoC) 2021. Authors analyzed the consequences on the ECoC Novi Sad (Serbia).

Methodology - The research was conducted in the form of interviews with representatives of the leading institutions related to the ECoC project and tourism of the City of Novi Sad, institutions in the field of the ECoC project management, tourism and creative industries, as well as the leading institution for tourist promotion of the City.

Findings - The main findings are indicating the fact that respondents' marketing and management concepts, applied in the previous year of the crisis, are proactive and reflected in the following activities: planning, organizing, communicating, controlling. The main issues were related to the following topics: Modifications in the business since the moment when the COVID-19 pandemic was declared until today; Assessment of the travel risk/benefit perception and activities related to mitigation/exploitation of such circumstances and; Recommendations in the field of the crisis management segment for the next ECoC.

Contribution - This research will focus on building a knowledge base for various stakeholders from different sectors in terms of developing the guidelines for the risk management strategies. Keywords: COVID-19, European Capital of Culture, Novi Sad, tourism, crisis management.
\end{abstract}

\section{INTRODUCTION}

Political changes in Eastern Europe were predicted to affect the attraction of this tourism market on the basis of the competition growth (Swarbrooke 2002, 372). This prediction began to be realized with the establishment of political and economic stability in parts of the Eastern Europe at the beginning of the $20^{\text {th }}$ century. Increased number of the people from the West considered the new political climate in the East as a possibility to visit the various tourism attractions, starting from the natural attractions to museums, galleries, 
ToSEE - Tourism in Southern and Eastern Europe, Vol. 6, pp. 195-213, 2021.

A.S. Dragin et al.: COVID-19 RISK MANAGEMENT PERSPECTIVES OF THE EUROPEAN ...

as well as different events, such as music festivals, or some other kind of cultural manifestations. The sightseeing of the cultural attractions in Eastern Europe enables an insight into the extraordinary collections in the museums and galleries, which is a consequence of the state support for the culture in the past (Swarbrooke2002, 372; Page and Hall 2003, 193).

The City of Novi Sad represents a good example of such practice and it has become popular as a festival city, the city of culture, a cruise port, a multicultural place, a youth spot, etc. Regarding these important facts, this city gained a title of the European Youth Capital for 2019, as well as a title the European Capital of Culture (ECoC) for 2021 (Majstorović et al. 2021). Actually, it is the first time that the city outside the EU boundaries gained the ECoC title (as a city from the country that is considered as a candidate for the EU membership).

The City of Novi Sad contains various competitive advantages in tourism terms. However, its favourable geographical position on the middle course of the Danube River might be considered as one of the most important advantages. It could also be said that it represents significant economic, administrative and cultural centre of the region, the city of a medium size, where 26 national minorities live together. The City of Novi Sad is recognized as a safe, healthy and stimulating place for living, but also for working and investing opportunities. Besides that, it is also perceived as a modern, tourist, cultural, university, political and administrative centre of the Autonomous Province of Vojvodina, as well as the city of museums, galleries, theatres and the festival city of international importance.

The Novi Sad 2021 Project is focused on increasing the further cultural vitality of the City of Novi Sad, on the basis of strengthening the cultural institutions, renewing the cultural heritage, developing the creative industries, decentralization and cross-sectoral cooperation. All together is supposed to be as beneficial for improving the international reputation of the City, but also the entire country (Jaguzović 2019; Majtorović 2021).

The Project was developed for five years, starting from the day of receiving the title. Suddenly, during the year before the titled year, the COVID-19 pandemic occurred, causing the unprecedented impact on tourism in global terms (Table 1).

Table 1: Tourism and the global crisis - Summary of indicators on the crises

\begin{tabular}{|c|c|c|c|c|}
\hline Crisis Year & $\begin{array}{l}\text { Sept } 11^{\text {th }} \\
\text { attacks } \\
2001 \\
\end{array}$ & $\begin{array}{l}\text { SARS } \\
2003\end{array}$ & $\begin{array}{l}\text { Global econ. } \\
\text { crisis } \\
2009 \\
\end{array}$ & $\begin{array}{c}\text { COVID-19 } \\
2020-\ldots\end{array}$ \\
\hline $\begin{array}{l}\text { World arrivals } \\
\text { (\% change) }\end{array}$ & $+0.1 \%$ & $-0.4 \%$ & $-4.0 \%$ & $-74 \%$ \\
\hline Month o (zero) & $\begin{array}{c}\text { September } \\
2001\end{array}$ & $\begin{array}{c}\text { March } \\
2003\end{array}$ & $\begin{array}{c}\text { January } \\
2009\end{array}$ & $\begin{array}{c}\text { January } \\
2020^{*}\end{array}$ \\
\hline $\begin{array}{l}\text { N. of months } \\
\text { for growth recovery }\end{array}$ & 5 & 5 & 10 & $18+$ \\
\hline $\begin{array}{l}\text { N. of months } \\
\text { for returning to the previous } \\
\text { volumes }\end{array}$ & $\begin{array}{c}14 \\
\text { (fact) }\end{array}$ & $\begin{array}{c}11 \\
\text { (fact) }\end{array}$ & $\begin{array}{c}19 \\
\text { (fact) }\end{array}$ & $\begin{array}{c}30-48 \\
\text { (predictions) }\end{array}$ \\
\hline
\end{tabular}


ToSEE - Tourism in Southern and Eastern Europe, Vol. 6, pp. 195-213, 2021. A.S. Dragin et al.: COVID-19 RISK MANAGEMENT PERSPECTIVES OF THE EUROPEAN ...

Table 1 (continued)

\begin{tabular}{lcccc}
\hline \multicolumn{1}{c}{ Crisis Year } & $\begin{array}{c}\text { Sept 11 } \\
\text { attacks } \\
2001\end{array}$ & $\begin{array}{c}\text { SARS } \\
2003\end{array}$ & $\begin{array}{c}\text { Global econ. } \\
\text { crisis } \\
2009\end{array}$ & $\begin{array}{c}\text { COVID-19 } \\
2020-\ldots\end{array}$ \\
\hline $\begin{array}{l}\text { World receipts } \\
\text { (real change, \%) }\end{array}$ & $-2.0 \%$ & $-1.7 \%$ & $-5.4 \%$ & $-20 \%$ to $-30 \%$ \\
Most impacted region & Americas & Asia Pacific & Europe & Asia Pacific \\
$\begin{array}{l}\text { Region's arrivals } \\
(\% \text { change) }\end{array}$ & $-5.9 \%$ & $-9.4 \%$ & $-5.3 \%$ & $-84 \%$ \\
\hline
\end{tabular}

* 31 December 2019: cluster of cases of pneumonia reported in the city of Wuhan (China)

13 January 2020: First novel COVID-19 case reported outside China in Thailand

23 January 2020: Wuhan lockdown

29 January 2020: Surge in flight cancellations to China

30 January 2020: WHO declares outbreak global health emergency

31 January 2020: USA restricts travel from China

Source: UNWOT 2020a, 2020b; Dragin et al. 2021b; Statista 2021a

The COVID-19 virus resulted in almost one hundred million cases of infected individuals and two million deaths (WHO 2020). Such conditions indicated the constant looking for a knowledge that would support the crisis management in rapidly changing market conditions. Considering the global situation caused by the COVID-19, numerous organizations that are operating in the field of tourism and hospitality reopened their business units, after required closure in the period between March and June 2020. No matter the fact, business units had to implement a set of health and sanitary measures after their reopening. These measures were related to required changes in terms of allowed number of people (in the same place at the same time), as well as the measures related to a mandatory wearing of masks for both, employees and tourists. Sanitary measures were mainly related to cleaning and disinfection of the public and private areas more often during a day, as well as to the prohibition of the self-service in areas with food (Marques Santos et al. 2020; Dragin 2021b). All aforementioned measures were periodically introduced, as stronger (closure of the state borders, lockdowns, etc.) or weaker, while some of them were even periodically abolished. But, it became clear that such measures will be active as long as the virus is present. More than 100 millions of jobs in tourism industry were lost during the 2020, or more precisely 63.4 million in Asia Pacific, 13 million in Europe, 8.2 million in North America, 7.6 million in Africa, 4.7 million in Latin America, 2.6 in Middle East and 1.2 million in Caribbean region (Statista 2021b). The question is, what about the capital projects in tourism and how did the crisis, caused by the COVID-19 pandemic, affect the individual destinations that based their development on international tourist arrivals. In respect to that, two main issues appeared in this research:

- The COVID-19 consequences on the European Capital of Culture projects (ECoC) and

- challenges managers are facing in new tourism era in that kind of projects. 
ToSEE - Tourism in Southern and Eastern Europe, Vol. 6, pp. 195-213, 2021.

A.S. Dragin et al.: COVID-19 RISK MANAGEMENT PERSPECTIVES OF THE EUROPEAN ...

\section{LITERATURE REVIEW}

The European Capital of Culture (ECoC) was established in 1985, as the Project and prestigious event for emphasizing the richness and diversity of the European cultures and 60 cities gained this opportunity, until 2019. Important ideas of the Project are related to strengthening the cultural connections between Europeans, connecting the people from different European countries and promoting their mutual understanding and joint cooperation. The Fund of the EU is supporting this Project on the basis of financial resources and also with the knowledge backup. In local and national terms, this Project enables significant development of infrastructure, employment opportunities for locals, development of tourism and significant financial effects, besides an opportunity for representation of their rich culture (Jaguzović 2009).

The City of Rijeka (Croatia), was one of the ECoC cities in the first year of the COVID19 pandemic (2020). The preparation for that title required five-year long business activities in Rijeka, with a lot of expectations. However, the COVID-19 pandemic cut the number of tourist arrivals and it caused recorded decrease of $63 \%$ in that city (compared to the 2019, MINTHR, 2021). It is estimated that around 200,000 of tourists visited Rijeka in 2020, out of 1,000,000 of expected visitors. Besides that, 500 out of the 600 planned programs were implemented, mainly in a modified form (online or with a limited number of visitors). The number of direct employees in the organization of the Rijeka ECoC was reduced from 70 to 14, due to the outbreak of the pandemic (March 2020), while in the period June-December2020, this number increased to 24 (Majstorović et al. 2021).

The City of Novi Sad has faced with the need for rapid and significant changes, in line with development of the pandemic (ECoC for 2021). However, managers did not have experience in the field of dealing with uncertainties caused by the COVID-19 virus and they did not (and they still could not) predict when the crisis will be over. For that purpose, interviews with decision makers were conducted. It was especially important to determine the following issues:

- What have they undertaken/modified in their management and business strategies since the moment when the pandemic was declared?

- What marketing and management concepts were implemented and changed in the researched period?

\subsection{The ECoC Management Concept}

The title of the ECoC is usually considered as an opportunity for further development of particular city, but also the whole country where it is situated. The title also represents a step forward development, not only in the field of culture, but also in the field of tourism and other activities and it could be considered as a driver of positive change in a society, with the main aim of securing the strong local and regional commitment to the project. The main focus is on strengthening cultural institutions, renewal of cultural heritage, strengthening cultural participation, development of cultural and creative industry, crosssectoral cooperation and finally development of tourism (Hansen and Laursen 2015; Jaguzović 2019). Aforementioned tasks are incorporated in the main tendencies of all 
ToSEE - Tourism in Southern and Eastern Europe, Vol. 6, pp. 195-213, 2021.

A.S. Dragin et al.: COVID-19 RISK MANAGEMENT PERSPECTIVES OF THE EUROPEAN ...

stakeholders involved in organization and realization of the ECoC (Jaguzović 2019), that are all together contributing to development of the project (Hansen and Laursen 2015).

Gaining the ECoC title is considered as a prestigious nomination for the city and it is followed by a one year-long programme with extensive planning procedure that often last for several years. It includes formulation of core ideas, outlining the bid, writing the applications, as well as the final evaluations of the ECoC year outcomes. Generally speaking, the entire event management of the $\mathrm{ECoC}$ might be divided into the two main phases: the process of applying procedure, as the first one, and realisation of its programme, as the other, which requires significant differences in overall organisation of these two parts (Hansen and Laursen 2015).

\subsection{The ECoC Marketing Concept}

Integration of cultural activities of the ECoC programme should develop relationships between different domains, such as culture, education, tourism, territorial planning, social services, etc. in order to help in building the sustainable partnerships with economic and social sectors, which is the main reason of considering the ECoC marketing as a sustainable one. Despite the fact that there are no strict requirements for marketing of the ECoC programme, most of the title cities made significant investment in marketing. However, it should be indicated that there are often significant differences in the budget amounts planned for the marketing activities, mostly as a consequence of the city governments' tendency to compete in performances of their duties and to provide different value for the public, comparing to the previous ECoCs. Besides that, planning of the marketing activities has an important role in the process of competition for the ECoC title, considering the fact that there is a need of providing the integration of the $\mathrm{ECoC}$ project into the common strategic plan of the city and its marketing. Appropriate marketing communication activities of the $\mathrm{ECoC}$ are important, not only during the year of the title, but also in the period of its preparation. Digital marketing is among the most funded priorities in normal circumstances, while it gained special importance in extraordinary circumstances, such as the COVID-19 circumstances (Burksiene, Dvorak and Burbulyte-Tsiskarishvili, 2018).

\subsection{Risk Management}

Previous findings related to the topic of the management actions in time of the crises pointed two types of the managers' behaviors, adaptive and non-adaptive one. Mao et al. (2020) and Mijatov et al. (2021) highlighted the need for constant learning and adaptation to new circumstances, in terms of the management actions. In respect to that, this research is oriented towards the manners in which the ECoC was affected by the COVID19 pandemic, with the example of the City of Novi Sad - in the first and in the second year of the crisis.

The number of tourist arrivals in Novi Sad in 2020 represents only $34.7 \%$ of the turnover for the previous year in this city (SORS 2021). However, compared to the $2020 \mathrm{ECoC}$ cities, the city of Novi Sad got additional year to find appropriate solutions to get as 
ToSEE - Tourism in Southern and Eastern Europe, Vol. 6, pp. 195-213, 2021.

A.S. Dragin et al.: COVID-19 RISK MANAGEMENT PERSPECTIVES OF THE EUROPEAN ...

much benefits as possible from the ECoC title during the crisis time. In order to better understand this issue, questions related to potential tourists and assumptions about their perception related to travel risks, or even though travel benefits that somebody might have during a pandemic, have also emerged.

Findings of the previously conducted studies indicated the fact that the main reasons for decreased number of international tourist arrivals during the COVID-19 pandemic is mainly related to the travel restrictions (UNWTO 2020a) and tourists' perception of the risks, termed as the "fear of travelling" (Marques Santos et al. 2020). Travel risk perception represents the topic of numerous previously conducted studies (Chiao and Vikneswaran 2014; Dirk 2003; Dowling and Staelin 1994; Hussain Fusté-Forné and Simmons 2021; Kovačić et al. 2019; Sánchez-Cañizares et al. 2020; Sönmez and Graefe 1998; Pizam and Mansfeld 1996; Floyd et al. 2004; Moreira 2007; Reisinger and Mavondo 2005; Williams and Balaž 2013). On the other hand, Hansen and Laursen (2015) indicated several risks directly linked to the ECoC stakeholders, mainly related to the challenge of changing the project life-cycle, from considering the ECoC as a project to realisation of the ECoC programme. Another challenge was related to a concurrent change of the management, as well as to the challenge of managing the activities and interpersonal relations between various types of stakeholders. All aforementioned risk types might occur as a matter of changing the organisational structure of the ECoC and a level of its complexity through different phases of the overall organisation (Hansen and Laursen 2015). As it could be seen, there are previously conducted studies focused on different risk types that might occur for the ECoC stakeholders. No matter the fact, this is one of the first studies focused on researching the ECoC managers' perceptions of the COVID-19 influence on their planned activities and overall consequences on tourism, considering the effects of global pandemic health crisis. Therefore, this research was focused on the managers with the aim to build a knowledge base related to developing the guidelines for the risk management strategies during the pandemic time.

\section{METHODOLOGY}

Respondents were chosen on the basis of the fact that they are considered as relevant, important, as well as sufficient source of information regarding the observed topic in the field of managing as well as marketing activities and with the position to be in direct communication with different stakeholders (local community, visitors/artists, audience/political public bodies, etc.). All of them preferred to answer the interview questions by e-mail. Collected interview data were summarised and coded by using the thematic analysis with data driven inductive-realistic epistemological approach, leaving out any theoretical preconception so far (Terry et al., 2017; Robson \& McCartan, 2016). This approach was identified as the most fitting with the main goal of this research, oriented towards discovering the manner in which decision makers and managers in tourism (managers) changed their plans regarding their activities during the unknown circumstances, caused by the COVID-19 pandemic, with the special reference to the activities planned within the ECoC Project. In addition, this research was also aimed at coding the collected data without imposing any kind of preconception, on the basis of 
ToSEE - Tourism in Southern and Eastern Europe, Vol. 6, pp. 195-213, 2021.

A.S. Dragin et al.: COVID-19 RISK MANAGEMENT PERSPECTIVES OF THE EUROPEAN ...

the lack of theoretical frameworks and guidance for managers and their activities during such kind of crisis.

\subsection{Interview participants and interview questions}

The interviews were conducted with six managers from Tourist Organisation of Novi Sad (TONS), from cultural stations of Novi Sad (CULST), from the Gallery of Matica Srpska (GAMS) and from the Foundation "Novi Sad- European Capital of Culture" (FONS). They were asked to answer the questions related to the impact of the COVID19 pandemic on their planned business activities. The main issues discussed through the interview were related to the following topics: Modifications in the business since the moment when the COVID-19 pandemic was declared until today; Assessment of the travel risk perception and activities related to mitigation of such circumstances; Assessment of the travel benefit perception and activities related to exploitation of such circumstances and; Recommendations in the field of the crisis management segment for the next ECoC.

The questions asked to the respondents within the abovementioned topics are the following ones:

1. Modifications in the business since the moment when the COVID-19 pandemic was declared until today:

- What did you modify in your business since the moment when the COVID-19 pandemic was declared until today?

- in planning of usual daily activities:

- $\quad$ in organizing events:

- $\quad$ in motivating all stakeholders:

- $\quad$ in terms of employees (number of employees, their working hours ...):

- in controlling the realization of events:

- in communication with employees/customers/tourists/business partners, associates / the media / the city authorities / the EU / the local population:

- $\quad$ something else:

- If you have implemented any of the above changes since the outbreak of the pandemic, what prompted you to make those changes - What were the milestones for such changes in the planned business activities?

- Were you exclusively guided by the recommendations of the crisis headquarters or did you have the liberty to decide for yourself? If so, what could you do on your own initiative?

- Did you have any other source of information and finding solutions, apart from the state competent institutions?

2. Assessment of the travel risk perception and activities related to mitigation of such circumstances:

- In your opinion, what can tourists perceive during the pandemic as a potential risk when they should travel to Novi Sad - the ECoC? For each group, enter the degree of risk $(1,2,3)$ next to the type of risk: A health risks (possibility of the COVID19 infection), B non-health risks - lower quality of service (smaller number of 
ToSEE - Tourism in Southern and Eastern Europe, Vol. 6, pp. 195-213, 2021.

A.S. Dragin et al.: COVID-19 RISK MANAGEMENT PERSPECTIVES OF THE EUROPEAN ...

employees, closed museums...), C non-health risks - reduced enjoyment (restriction of movement, wearing masks...).

- Could you do something in the field of marketing / management in terms of reducing the perception of risk among the potential tourists?

3. Assessment of the travel benefit perception and activities related to exploitation of such circumstances:

- What do you think tourists can recognize during the pandemic as an advantage when they should travel to Novi Sad - the ECoC? For each group, write next to the advantages the degree of attractiveness $(1,2,3)$.

- Could you do something in the field of marketing / management in terms of emphasizing the newly created advantages to make potential tourists to be aware of the potential visiting of Novi Sad?

4. Recommendations in the field of the ECoC crisis management:

- What would you recommend to the next ECoC from the crisis management segment?

\section{RESULTS}

\subsection{Modifications in the business since the moment when the COVID-19 pandemic was declared until today}

Planning of usual daily activities. When asked what they modified in their business since the moment when the COVID-19 pandemic was declared until today, managers from the FONS stated:

"In planning the daily activities, we adjusted to requirements of the city and the state, and when necessary, we organized work from home and then in shifts, such as 2 days in offices, 3 days from home. Everything worked well thanks to the fact that all employees have laptops and we also have Microsoft share point software support, so all our documents are centralized in one place. The employees returned to their jobs, when the overall situation became better."

All interviewed managers indicated that the impact of the COVID-19 pandemic, unfortunately, contributed to the reduction of the number of tourists, both domestic and foreign. In respect to that, managers were forced to reduce their planning of usual daily activities to maximum, as well as to change them into an online format. Therefore, their daily activities were more oriented towards statistical business tasks and online campaigns. Interviewed managers made some changes in terms of the work schedules, the manner of realization of events (transition to an online mode), the manner and dynamics of communication with the audience (in situations of changing dates and/or cancellation of events), the manner of receiving the audience (temperature measurement, hand spraying, etc.), increased maintenance of hygiene, monitoring the health of employees and isolation in the case of the contact with the patients. 
ToSEE - Tourism in Southern and Eastern Europe, Vol. 6, pp. 195-213, 2021.

A.S. Dragin et al.: COVID-19 RISK MANAGEMENT PERSPECTIVES OF THE EUROPEAN ...

Organizing events. Managers from FONS described the changes in their activities related to organizing the events, saying that:

"In planning the events, we adapted to requirements of the state and the city and adhered to epidemiological measures, while in the previous months the events were completely postponed, canceled or suspended. Even in the summer of 2020, when the epidemiological measures subsided, we organized cultural events and a competition for the affirmation of young artists. The events were held in open spaces."

Managers from the GAMS stated that:

"The Gallery of Matica Srpska organized programs tailored to the individual enjoyment of the exhibition, such as the "Art Room" in which visitors could enjoy in watching one selected work of art alone. Instead of the workshops for children, the program 'Family Day' was designed for those who want to spend the joint time in the museum."

Besides moving to an online event format, all interviewed managers indicated that they also had to adhere with a limited number of performers and audiences, including the email registration and audience schedule (required intervals are defined in accordance with the currently valid measures). Certain types of events that are of high risk were not realized (performances of choirs, vocal performers, and other forms of collective performances that involve direct physical contact between performers). They also had to indicate flexibility in scheduling events due to the frequent changes in prescribed health measurements.

Motivating all stakeholders. Interviewed managers tried to keep their employees motivated, above all, through providing the regular salaries and possibilities for work from home. They highlighted the fact that they were in a daily communication with both, decision makers, as well as international, regional and local scene, via emails, telephone conversations and Microsoft teams, Skype and other communication applications. With return to offices, live meetings have been organized in $90 \%$ of the cases.

Overall situation in terms of motivating the stakeholders was described by the managers from the CULST, as following:

"In terms of motivating the actors on stage, i.e. participants and performers of the program, we prepared a public call "Artists! Now" which significantly helped the scene at the moment when it was the most needed. Also, performers were supported in the realization of online events for which performers themselves did not have the capacity to organize alone. Such support enabled them to work, because performing without an audience in the virtual world would not make sense. The audience is motivated through the PR activities, by regularly sending information to the mailing list that exists within the database of cultural stations, as well as by insisting on the strict adherence to measures and hygiene."

Managers from the GAMS described their activities in the field of motivating all stakeholders in the following manner: 
ToSEE - Tourism in Southern and Eastern Europe, Vol. 6, pp. 195-213, 2021.

A.S. Dragin et al.: COVID-19 RISK MANAGEMENT PERSPECTIVES OF THE EUROPEAN ...

"We organized online contents, aimed not only at presentation of the program, but also at creating the interactive content in which the audience participated directly by giving their comments, involvement in video guides, as well as by sending their photos for the "Art Challenge", answering the questions in the online art quiz..."

Employees. When asked what they had to change in terms of the employees (number of employees, working hours...), managers from the CULSTstated that:

"The format of work from home has been introduced, i.e. online presence, work model $3+2 ; 4+1$ at work and work from home, shift hours are combined in the sense that half of the working time is in the physical space, half online, etc. All prescribed measures in terms of providing the necessary conditions were adhered (distance, masks for employees, hygiene products, etc.). The number of employees in the communications sector even increased in the fall of 2020."

Controlling the realization of events. All interviewed managers indicated that special duty shifts were introduced for the entrance to the events - two employees at the entrance who measured the temperature and sprayed the visitors' hands with disinfectants, during the event they controlled whether the audience wore masks or took them off, intervened by asking someone who did not respect the measures to leave the event, etc.

Managers from the FONS described their activities in the field of controlling the realization of events:

"We monitored the events on a daily basis and gave our maximum support in their promotion. Situation with the realization of events is still unresolved, but we hope that the upcoming big events in the City, such as "Sterijno Pozorje" and "Exit Festival", will be a good test for the title year. Also, with the growing number of vaccinated citizens in Novi Sad and the region, we believe that the year of the title 2022 will be held at full capacity, in terms of the program. Tourists and visitors from foreign countries might be absent, but we believe that the events organized within the ECoC will be visited by tourists from the region."

Communication with employees. Maximum availability of all employees and exchange of business ideas via Viber, emails and similar communication channels, were stated as the main standards in the communication of all interviewed managers and their employees. Thematic meetings on compliance with measures were organized, all employees received general information on the rules and measures, employees were encouraged to freely express if they are concerned regarding the risk contacts and they had the information that their sick-leave in the case of the COVID-19 infection will be fully refunded.

Communication with users/tourists. Interviewed managers indicated that tourists, as always, could reach them by-email or phone number. One of the colleagues was always available in their Info Centers. Managers from the FONS also stated: 
ToSEE - Tourism in Southern and Eastern Europe, Vol. 6, pp. 195-213, 2021.

A.S. Dragin et al.: COVID-19 RISK MANAGEMENT PERSPECTIVES OF THE EUROPEAN ...

"Unfortunately, number of tourist arrivals has almost disappeared, but during the COVID-19 pandemic we began to prepare a large number of promotional materials, videos and activities that will attract tourists to the destination immediately after the mitigating of the prohibition measures and restrictions on movement. The media campaign to attract tourists and visitors of cultural and artistic programs has been slowly intensifying, especially through the platform www.visitns.rs and other Instagram and Facebook communication channels."

Communication with business partners/associates has not changed its form, but it changed its intensity in a direction of more frequent exchange of information on currently valid measures and opportunities for the implementation of the program. Managers from the TONS indicated that:

"We tried to help them and support their campaigns. As for the hotel, we made a 2 +1 action for free (overnight) and a large number of hotels responded to that action."

On the other hand, managers from the TONS highlighted the following:

"As for the agencies, we created tour proposals and forwarded them to all agencies in Novi Sad."

Communication with the media. Managers from the CULST indicated that the way of communication with the media has not been changed in terms of the form and usual channels of communication, except in the case of the project organized to support the local scene "Artists! Now", this is more intensively promoted in the media and marketing activities. Managers from the TONS and the GAMS stated that their PRs regularly communicated and reported to the media regarding all of their activities, tourist arrivals and similar important facts.

Managers from the FONS described their activities in the field of communication with the media in the following manner:

"Everything was clearly communicated through electronic forms of communication and online meetings and it functioned at a very high and satisfactory level. We tried to make sure that the campaign for the title year never stopped. Since it was moved from 2021 to 2022, when the European Commission made that decision and when it was adopted by the European Parliament in December 2020, we launched an intensive campaign to explain that the year of the title was moved. Now the word is alive again and communication is at a high level, a large number of media reports on our events and activities."

Communication with the city authorities. All interviewed managers indicated that more direct communication has been established with the line secretariats, the crisis headquarters and other competent bodies, especially in cases where there was a need to interpret the certain measures that were not sufficiently clearly formulated. 
ToSEE - Tourism in Southern and Eastern Europe, Vol. 6, pp. 195-213, 2021.

A.S. Dragin et al.: COVID-19 RISK MANAGEMENT PERSPECTIVES OF THE EUROPEAN ...

Communication with the EU. Managers from the FONS were in intensive communication with the EU, considering their role in organization of the ECoC, comparing to other interviewed managers, and they stated the following:

"We received a great support and understanding from them. Together with the remaining cities, holders of the title for 2021 and 2022, we sent initiatives to move the year of the title (someone for 2022 and someone for 2023). In agreement with the Mayor, Novi Sad chose to be the holder of the title for 2022."

Communication with the local population. Interviewed managers indicated that, since the movements were limited as well as the gatherings, they tried to reach the local population through the social networks, print and electronic media and websites. They also tried to keep the enthusiasm and give different suggestions on how tourists can spend the weekend within the environment of the local population, which places to visit, where to have lunch, where to go with the family, how to spend a romantic weekend, etc.

\subsection{Assessment of the travel risk perception and activities related to mitigation of such circumstances}

Managers indicated that, in their opinion, there is a fear of the health risk (possibility of the COVID-19 infection), non-health risks - lower quality of service (smaller number of employees, closed museums...) and non-health risks - reduced enjoyment (restriction of movement, wearing masks...). However, they also believe that aforementioned fears are not crucial for giving up on the travel and visiting Novi Sad as the ECoC. Interviewed managers believe that there are not differences in aforementioned fears among the tourists on the basis of their gender. On the other hand, interviewed managers believe that older tourists might consider the fear of reduced enjoyment as crucial for giving up the travel. They also believe that tourist who travel with the family members might consider the health risk as crucial. Finally, domestic and tourists from the region might show less concerns regarding the aforementioned risks, compared to the respondents from China, Middle East, but also from the EU countries.

In the field of marketing, in terms of reducing the perception of the risk among the potential tourists, managers from the TONS created mini films that promote Novi Sad as the future European Capital of Culture, encouraging people to travel and make sure that Novi Sad is really safe for both domestic and foreign visitors. On the other hand, in the field of management, also in terms of reducing the perception of risk among the potential tourists, all interviewed managers pointed out the following measures as required: respecting the epidemiological measures, keeping a distance, wearing masks for sure. They also highlighted that it is important to slowly start with the realization of the events, visits to wineries, with a limited number of people in order to enable the people to relax and slowly return to the normal course of daily activities. Managers also believe that it is necessary for the top and the middle managers to organize the basic education in the field of the crisis management, as already mentioned. 
ToSEE - Tourism in Southern and Eastern Europe, Vol. 6, pp. 195-213, 2021.

A.S. Dragin et al.: COVID-19 RISK MANAGEMENT PERSPECTIVES OF THE EUROPEAN ...

\subsection{Assessment of the travel benefit perception and activities related to exploitation of such circumstances}

All interviewed managers expressed their attitudes on what could tourists recognize during the COVID-19 pandemic as an advantage when coming to Novi Sad - the European Capital of Culture. They agreed that absences of the crowd, noise, as well as free places in cafes are recognized as attraction, but not crucial for going on the travel such as lower accommodation prices could be.

Interviewed managers also believe that it is necessary to do something in the field of marketing in terms of emphasizing the emerging benefits to make potential tourists aware of them and to visit Novi Sad. Managers from the TONS stated that, through their campaigns, called 52 weekends in Serbia, a wide range of a large number of tourist products is included, not only in Novi Sad, but in the whole of Serbia. These campaigns include wineries, gastronomy, accommodation, active holidays and many other things related to Serbia that is extremely attractive to tourists. Role of the management in terms of emphasizing the newly created advantages to make potential tourists aware of potential visiting of Novi Sad is also important. In respect to that, interviewed managers highlighted that only through the implementation of ideas related to the belief that their $\mathrm{ECoC}$ will be successful even in the time of the crises, it is possible to send a true message that the overall situation with the COVID-19 virus is slowly passing and that things are returning to normal.

\subsection{Recommendations in the field of the crisis management segment for the next ECoC}

All interviewed managers highlighted the need for the quick adaptability to changes and as much brainstorming as possible. In order to grow and develop, it is necessary to quickly adapt even to changes that bring the negative aspects with them, as was the case with the COVID-19 virus. These changes also include the activities related to redefining the communication strategy when it is necessary, for making it more appropriate, as well as for gaining the aim in the crisis time. Besides that, they also indicated the need for the mandatory education of the top and the middle management in the field of the crisis management. Specific advice in relation to this situation applies only to this situation, but it is also necessary to emphasize the importance of internal PR and quality information to employees about the situation and all important information, as well as quality information to the general public and the following measures.

\subsection{Executive Interview Summary}

Interviewed managers highlighted that introduction of emergency measures and restrictions on movement, as well as closure of cultural institutions directed the application of new concept of work and acceptance of the fact that in new situation only institutions that will adapt to new requirements and challenges will survive, adapting their work to needs of the audience above all. In respect to that, managers from the FONS indicated that they were even motivated to use the overall situation for being the best 
ToSEE - Tourism in Southern and Eastern Europe, Vol. 6, pp. 195-213, 2021.

A.S. Dragin et al.: COVID-19 RISK MANAGEMENT PERSPECTIVES OF THE EUROPEAN ...

ECoC ever, by using their sources, such as people, processes, spaces and the program. Besides that, all interviewed managers highlighted the importance of motivating the stakeholders, involved in the ECoC Project. Interviewed managers were mainly guided by decisions of the crisis headquarter and they tried to respect all prescribed measures, both for employees and for visitors. They also followed the recommendations of the competent Ministry for Culture. However, on their own initiative, they did not accept the realization of specific events assessed as of high-risk. Causal thematic network illustrates this summary (Figure 1).

Figure 1: Causal network of key constructs in the ECoC crisis management

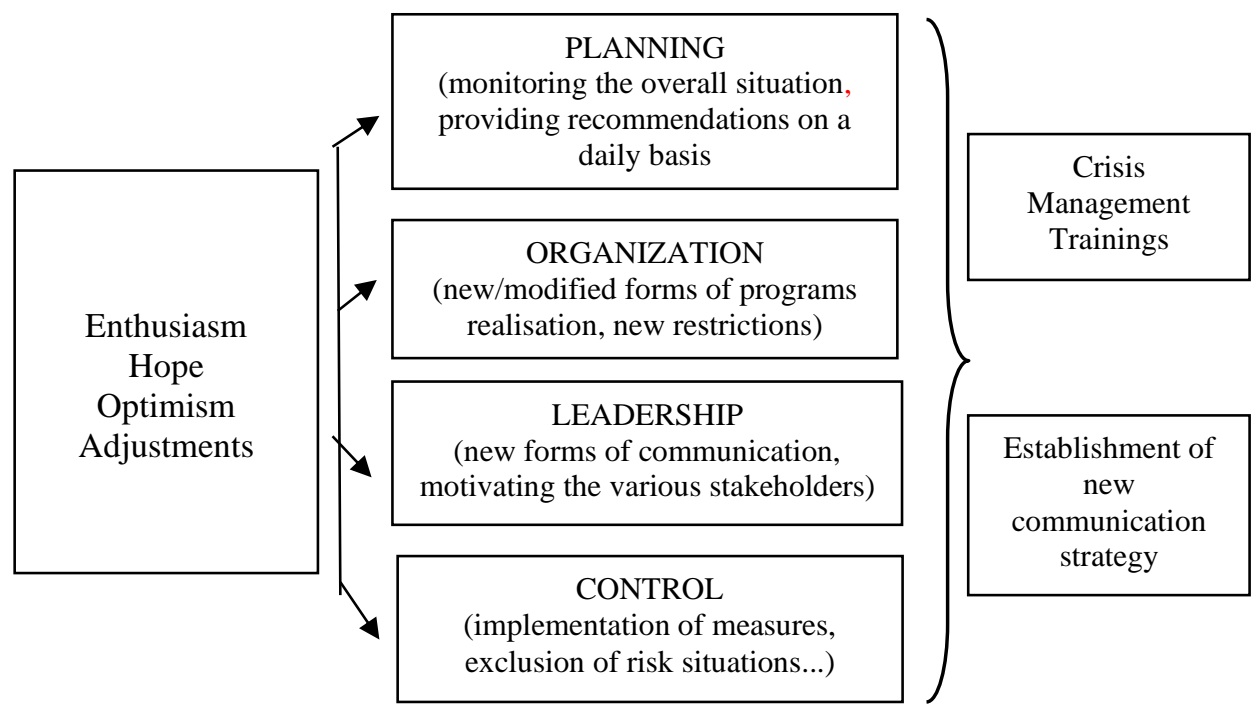

\section{DISCUSSION AND CONCLUSION}

This research was conducted in order to determine the manner in which decision makers and managers in the City of Novi Sad are facing with the challenges caused by the COVID19 pandemic. The City of Novi Sad was declared European Capital of Culture for 2021 (Majstorović et al. 2021), while the pandemic occurred one year earlier, with uncertain duration and significant consequences for the health, economy and lifestyle of the people across the globe (UNWTO 2020a, b; WHO 2020; Dragin et al. 2021a, b; Hussain FustéForné and Simmons 2021; Mijatov et al. 2021; Statista 2021a,b; Stankov et al. 2020).

The Novi Sad 2021 Project was designed as a platform for development of cultural and creative potentials of the City. The City, in joint efforts with its institutions, prepared this important Project for even five years. However, the pandemic significantly hindered the development of planned events. Specific consequences for the City, caused by the pandemic, are mainly related to a drastic decrease in the number of tourist arrivals, cancellation or modification of events and postponing the ECoC title for 2022, which is 
ToSEE - Tourism in Southern and Eastern Europe, Vol. 6, pp. 195-213, 2021.

A.S. Dragin et al.: COVID-19 RISK MANAGEMENT PERSPECTIVES OF THE EUROPEAN ...

already highlighted in the study conducted by Majstorović et al. (2021). In this paper, the main focus is on the management, with the special attention put on the following questions: What have decision makers and managers undertaken/modified in their management and business strategies since the moment when the pandemic was declared? What marketing and management concepts were implemented and changed in the researched period? It was also found that decision makers and managers mostly acted proactively rather than passively. The interview obtained representatives of the leading institutions related to the ECoC project and tourism of the City of Novi Sad, or more precisely institutions in the field of the ECoC project management (Foundation "Novi Sad- European Capital of Culture"), management/realization of the numerous events in the segment of culture (Cultural stations of Novi Sad - as the local institution and Gallery of Matica Srpska - as a national institution), as well as the leading institution for tourist promotion of the City (Tourist Organisation of Novi Sad). Their marketing and management concepts, applied in the previous 15 months of the crisis, can be seen as proactive and it is reflected in the following activities: planning (monitoring the overall situation and recommendations, changes on a daily basis), organizing (new programs, new forms of restrictions), communicating (new forms of communication, motivating different stakeholders), and controlling (implementation of the measures, exclusion of the risk situations...).

Regarding the perception of the main predictors of potential tourists' behaviour, interviewed decision makers and managers believe that health risk, as well as non-health risks (lower quality of services, reduced enjoyment) are not crucial in global for giving up on the travel and visiting Novi Sad as the ECoC. However, there are some differences between various groups of tourists (older/younger, individual travel/family travel, domestic tourists/tourists from the region/tourists from longer distances...). In respect to that, tourism managers highlighted that it is important to define new, appropriate communication strategy for gaining the aim of adequate performances in the time of the crisis.

On the basis of the interview findings, it could also be concluded that, due to the lack of the previous knowledge in the field of the crisis management, especially during the unfamiliar situation to all (the COVID-19 pandemic), decision makers and managers often acted intuitively and with a lot of enthusiasm, with expressed hope for gaining the positive effects. Explanation for such enthusiasm and orientation towards numerous and constant attempts to find appropriate solutions on their own might be found in the fact that managers involved in the ECoC Novi Sad Project and tourism development of Novi Sad are representatives of the generation (of former children and youth) from another great and long-term crisis - transition process within the Eastern Europe (the last decade of the $20^{\text {th }}$ century and the first decade of the $21^{\text {st }}$ century). Their expectations increased in line with finally favourable political, economic and social situation, which is the main reason why the ECoC became a symbol of the arrival of a better time for the population of the City of Novi Sad and even the region. Due to the belief in the success of the ECoC title realization, the management undertook certain activities to encourage the various stakeholders (employees, business partners, artists, the audience - potential tourists and the local population). In the final recommendations, the next ECoC was strongly advised by all interviewed decision makers and managers "not to panic, in order to properly decide on their next moves". Interviewed managers are even sharing the opinion that this will be the best ECoC project so far. Motivation of interviewed managers is also confirmed in the case 
ToSEE - Tourism in Southern and Eastern Europe, Vol. 6, pp. 195-213, 2021.

A.S. Dragin et al.: COVID-19 RISK MANAGEMENT PERSPECTIVES OF THE EUROPEAN ...

of the Gallery of Matica Srpska representatives, who gained the DISRUPT award of Adam studio marketing agency, for innovative models of museum communication achieved during the 2020, the first year of the crisis.

It is also important to indicate that, according to the managers' attitudes, absence of certain level of the panic due to the uncertainty caused by the pandemic is based on the continued process of business activities of all interviewed institutions, leaded by FONS, which is set on the values identified in line with the needs of the City within the ECoC Project. The concept is based on: people, processes, spaces and programs with the slogan "Beginning of the new. Now" (Novi Sad could be translated as "now now"). Managers in FONS, from very beginning, believe that education of the people in the sector of culture represents raising the City's capacity, while defining of the clear processes and procedures represent one of the most important results from the ECoC Project. The managers also believe that such significant Project, as well as the following huge Projects in the City, might be developed with success only with the people and processes. One of the permanent Project legates is new infrastructure in the function of tourism, culture and creative industries. The City made significant progress, by building and creating the new facilities in which culture became a way of life. Finally, the ECoC programs are already showing that permanent bridges have been built between once unrelated stakeholders through the process of implementing the ECoC Project, even before the title year: decision makers, citizens, tourists, as well as cultural and artist scene.

\section{Contribution to the theory and practice}

This research was focused on decision makers and managers, with the aim to build a knowledge base related to developing the guidelines for the risk management strategies during the pandemic time that will help contemporary and future ECoCs, when defining the risk management activities. Discussion of the paper provides theoretical contributions to the literature, by developing a valuable conceptual framework for identifying particular management risks on the basis of perceiving the influence of the COVID-19 outbreak on their planned activities. More precisely, authors found the following theoretical contribution as essential issues: (1) required modifications in the business since the moment when the COVID-19 pandemic was declared until today, (2) assessment of the travel risk perception and activities related to mitigation of such circumstances, (3) assessment of the travel benefit perception and activities related to exploitation of such circumstances, (4) recommendations in the field of the crisis management segment for the next ECoC. These findings, based on the statements and proposed solutions of the leaders involved in development of the ECoC project in Novi Sad in the time of the pandemic, could directly contribute to development of the risk management guidelines for different decision-makers involved in tourism and creative industry, operating during and after the crises, as well as for other stakeholders such as local communities, small and medium enterprises, which will, finally, be accompanied by prescribing the national strategy for tourism development. Furthermore, results could have the practical implications for the managers from the other sectors that are also affected by the pandemic. In terms of limitations, it could be said that this study was based on attitudes of managers, while further studies should be focused on other employees involved in organisation and realization of the ECoC. Finally, in order to complete and expand the overall findings of the COVID-19 influence on the ECoC 
ToSEE - Tourism in Southern and Eastern Europe, Vol. 6, pp. 195-213, 2021.

A.S. Dragin et al.: COVID-19 RISK MANAGEMENT PERSPECTIVES OF THE EUROPEAN ...

activities, visitors' perspective is also important issue, which represents another limitation of this study that might be enhanced in further research.

\section{ACKNOWLEDGEMENT}

This paper was founded under the project line ZIP UNIRI of the University of Rijeka, for the project ZIP-UNIRI-116-1-20.

\section{REFERENCES}

Burksiene, V., Dvorak, J. and Burbulyte-Tsiskarishvili, G. (2018), "Sustainability and sustainability marketing in competing for the title of European Capital of Culture", Organizacija, Vol. 51, No. 1, pp. 66-78. https://doi.org/10.2478/orga-2018-0005

Chiao, L.Y. and Vikneswaran, N. (2014), "Risk perception study in tourism: are we really measuring perceived risk?” Procedia Social Behav Sci, Vol. 144, pp. 322-327. https://doi.org/10.1016/j.sbspro.2014.07.302

Dirk, G. (2003), Crisis management in the tourism industry, 2nd ed., Butterworth-Heinemann, Oxford.

Dowling, G. and Staelin, R. (1994), "A Model of Perceived Risk and Intended Risk-Handling Activity", Journal of Consumer Research, Vol. 21 No. 1, pp. 119-135. https://doi.org/10.1086/209386

Dragin, A., Mijatov, M., Majstorović, N., Janičić, B. and Korovljev, D. (2021a), "COVID-19 Pandemic and Young Tourists, Travel Risk Perceptions: Impacts on Travel Restrictions (Local and International) and Tourism", in Brunn, S.D. and Gilbreath, D., COVID-19 and an Emerging World of Ad Hoc Geographies, Springer, United States. In press.

Dragin, A., Mijatov, M., Zadel, Z., Košić, K. and Pivac, T. (2021b), "The Impact of the Covid-19 Pandemic on Tourism", paper presented at the conference GEOBALCANICA, In press, ISSN 1857-7636.

Floyd, M.F., Gibson, H., Pennington-Gray, L., and Thapa, B. (2004), "The effect of risk perceptions on intentions to travel in the Aftermath of September 11, 2001", Journal of Travel Tourism Marketing, Vol. 15, No. 2-3, pp. 19-38. https://doi.org/10.1300/J073v15n02_02

Hansen, L.E. and Laursen, M. (2015), "From applicant to designated European Capital of Culture", International Journal of Managing Projects in Busines, Vol 8, No. 4, pp. 715-731. https://doi.org/10.1108/IJMPB-01-2015-0009

Hussain, A., Fusté-Forné, F. and Simmons, D. (2021), "Fear of Pandemics or Fear of Tourism: the Challenges for Human Mobility", Tourism and Hospitality Management, Vol. 27, No. 1, pp. 223-228. https://doi.org/10.20867/thm.27.1.3

Jaguzović, L. (2019), Stavovi studenata turizma o efektima Projekta Evropska prestonica kulture na razvoj turizma i imidža grada Novog Sada, Prirodno-matematički fakultet, Novi Sad, Serbia.

Kovačić, S., Jovanović, T., Miljković, Đ., Lukić, T., Marković, S.B., Vasiljević, Đ.A., Vujičić, M.D. and Ivkov, M. (2019). "Are Serbian tourists worried? The effect of psychological factors on tourists' behavior based on the perceived risk", Open Geosciences, Vol.11, No. 1, pp. 273-287, https://doi.org/10.1515/geo-2019-0022

Majstorović, N., Dragin A.D., Mijatov, M.B., Stojanović, V., Zadel, Z. and Zelenović Vasiljević, T. (2021), "Socio-Economic Sustainability of Cultural Tourism in Mediterranean during the COVID19Pandemic", in Buonincontri, P., Errichiello, L. and Micera, R., Tourism Studies on the Mediterranean Region: PostCovid-19 tourism: a pathway towards sustainable development in the Mediterranean region, McGraw-Hill publishing, New York. In press.

Marques Santos, A., Madrid González, C., Haegeman, K. and Rainoldi, A. (2020), Behavioural changes in tourism in times of COVID-19: Employment scenarios and policy options, European Commission - JRC Science for Policy Report, viewed 02. January 2021, https://publications.jrc.ec.europa.eu/repository/handle/JRC121262.

Mao, Y., He, J., Morrison, A.M. and Coca-Stefaniak, A.J. (2020), "Effects of tourism CSR on employee psychological capital in the COVID-19 crisis: From the perspective of conservation of resources theory", Current Issues in Tourism, Vol. 24, No. 19, pp. 2716-2734. https://doi.org/10.1080/13683500.2020.1770706

Mijatov, M., Dragin, A., Majstorović, N., Janičić, B. and Zadel, Z. (2021), "The Impacts of Covid-19 on Youth Tourism and Hospitality Managers In-Training", Brunn, S.D. and Gilbreath, D., COVID-19 and an Emerging World of Ad Hoc Geographies, Springer, United States. In press. 
ToSEE - Tourism in Southern and Eastern Europe, Vol. 6, pp. 195-213, 2021.

A.S. Dragin et al.: COVID-19 RISK MANAGEMENT PERSPECTIVES OF THE EUROPEAN ...

MINTHR (2021), n.d. Statistike, viewed February 2021, https://mint.gov.hr/pristup-informacijama/dokumenti80/statistike/11514.

Moreira, P. (2007), "Stealth risks and catastrophic risks: on risk perception and crisis recovery strategies", Journal of Travel Tourism Marketing, Vol. 23, No. 2, pp. 15-27. https://doi.org/10.1300/J073v23n02_02

Page, S.J. and Hall, M. (2003), Managing Urban Tourism, Pearson Education Limited, Edinburgh Gate, Harlow.

Pizam, A. and Mansfeld, Y. (Eds.), (1996), Tourism, crime and international security issues, John Wiley and Sons, Chichester.

Robson, C. and McCartan, K. (2016), Real world research, John Wiley and Sons, Chichester.

Reisinger, Y. and Mavondo, F. (2005), "Travel anxiety and intentions to travel internationally: implications of travel risk perception", Journal of Travel Research, Vol. 43, No.3, pp. 212-225. https://doi.org/10.1177/0047287504272017

Sánchez-Cañizares, S.M., Cabeza-Ramírez, L.J., Muñoz-Fernández, M. and Fuentes-García, F.J. (2020), "Impact of the perceived risk from Covid-19 on intention to travel", Current Issues in Tourism, Vol. 24, No. 7, pp. 970-984. DOI: https://doi.org/10.1080/13683500.2020.1829571

Statista (2021a), n.d., Globalchange in international tourism receipts due to COVID-19 2019-2020, Statista Research Department, viewed March 2021, https://www.statista.com/statistics/1109855/coronavirusinternational-tourism-receipts/.

Statista (2021b), n.d., Employment loss in the travel and tourism industry due to the coronavirus (COVID-19) pandemic worldwide in 2020, by region viewed May 2021, https://www.statista.com/statistics/1104835/coronavirus-travel-tourism-employment-loss/.

Stankov, U., Filimonau, V., and Vujičić, M. D. (2020), “A mindful shift: an opportunity for mindfulness-driven tourism in a post-pandemic world", Tourism Geographies, Vol. 22, No. 3, pp. 703-712. https://doi.org/10.1080/14616688.2020.1768432

SORS (2021), n.d., Information on tourist arrivals in Serbia for the period January-December 2020, report prepared by the Statistical Office of The Republic of Serbia, viewed April 2021, https://mtt.gov.rs/download/Turisti\%C4\%8Dki\%20promet\%20-\%20DECEMBAR\%202020.docx.

Sönmez, S.F. and Graefe, A.R. (1998), "Influence of terrorism risk on foreign tourism decisions", Annals of Tourism Research, Vol. 25, No. 1, pp. 112-144. https://doi.org/10.1016/S0160-7383(97)00072-8

Swarbrooke, J. (2002), The Development and Management of Visitor Attractions, (2nd ed.), ButterworthHeinemann, Linacre House, Jordan Hill, Oxford.

Terry, G., Hayfield, N., Clarke, V. and Braun, V. (2017), "Thematic Analysis", Stainton Rogers, W., and Willig, C., The SAGE Handbook of Qualitative Research in Psychology, (2nd ed.), SAGE, London.

UNWTO (2020a), n.d., UNWTO World Tourism Barometer May 2020, Special focus on the Impact of COVID19 (Summary), viewed February 2021, https://webunwto.s3.eu-west-1.amazonaws.com/s3fspublic/2020-05/Barometer\%20-\%20May\%202020\%20-\%20Short.pdf. Last assessed: 16/02/2021

UNWTO (2020b), n.d., Impact assessment of the COVID-19 outbreak on international tourism, viewed 03 January 2021. https://www.unwto.org/impact-assessment-of-the-covid-19-outbreak-on-internationaltourism.

Williams, A. M. and Baláž, V. (2013), "Tourism, risk tolerance and competences: travel organization and tourism hazards", Tourism Management, Vol. 35, pp. 209-221, http://dx.doi.org/10.1016/j.tourman.2012.07.006

WHO (2020), n.d., Coronavirus disease (COVID-19) Pandemic, viewed 1 December 2020, https://www.who.int/emergencies/diseases/novel-coronavirus-2019

Aleksandra S. Dragin, PhD, Full Professor

University of Novi Sad, Faculty of Sciences

Department of Geography, Tourism and Hotel Management

Trg Dositeja Obradovića 3, Novi Sad, Serbia

$+381638306114$

sadragin@gmai.com

Zrinka Zadel, $\mathrm{PhD}$, Associate Professor

University of Rijeka, Faculty of Tourism and Hospitality Management

Primorska 42, Opatija, Croatia

$+38551294183$

zrinka.zadel@fthm.hr 
ToSEE - Tourism in Southern and Eastern Europe, Vol. 6, pp. 195-213, 2021.

A.S. Dragin et al.: COVID-19 RISK MANAGEMENT PERSPECTIVES OF THE EUROPEAN ...

Maja B. Mijatov, PhD, Research Associate The Corresponding Author

University of Novi Sad, Faculty of Sciences

Department of Geography, Tourism and Hotel Management

Trg Dositeja Obradovića 3, Novi Sad, Serbia

+381642036990

majamijatov@gmail.com

Vladimir Stojanović, PhD, Full Professor

University of Novi Sad, Faculty of Sciences

Department of Geography, Tourism and Hotel Management

Trg Dositeja Obradovića 3, Novi Sad, Serbia

$+381641143686$

vladimir_stojanovic@yahoo.com

Tamara Jovanović, PhD, Associate Professor

University of Novi Sad, Faculty of Sciences

Department of Geography, Tourism and Hotel Management

Trg Dositeja Obradovića 3, Novi Sad, Serbia

+381643978881

jtamara@uns.ac.rs

Lazar Lazić, PhD, Full Professor

University of Novi Sad, Faculty of Sciences

Department of Geography, Tourism and Hotel Management

Trg Dositeja Obradovića 3, Novi Sad, Serbia

+38163518932

lazar.lazic@dgt.uns.ac.rs

Tamara Zelenović Vasiljević, $\mathrm{PhD}$, Chief of CEO office

Foundation "Novi Sad- European Capital of Culture"

Trg slobode 3, Novi Sad, Serbia

$+38162290099$

zvtamara@gmail.com

Nemanja Milenković, MSc, CEO

Foundation "Novi Sad- European Capital of Culture"

Trg slobode 3, Novi Sad, Serbia

$+381607202101$

nemanja.milenkovic77@gmail.com 